\title{
SILAT: IDENTITAS BUDAYA, PENDIDIKAN, SENI BELA DIRI, DAN PEMELIHARAAN KESEHATAN
}

\author{
Mila Mardotillah ${ }^{1}$, Dian Mochammad Zein ${ }^{2}$
}

\begin{abstract}
Silat is one identity of the archipelago martial arts in Indonesian cultures that contains as regards in education which evolve in the society. In the modern era, silat is not just as the tools of martial arts, but also branch out as an effort to maintain health through physical exercise. The function of silat also as media of physical education through some processes in own formal education institution which is each institution has different own rules. Identity is part of social cultures and environment that possible to change corresponding with life dynamic society. Identity develops suitable with the era of different generation in daily life society that originated from human thought and human behavior and develops being real practice. Physical and spiritual education which is taught by silat can creates nation characteristics which are tough, strong, and good attitudes, also develops being characteristics of Indonesia. As demand of the world in modern era, the function of silat develops being care taker for themselves, and of course it is as healthy maintains. So, between physical health and spiritual health are balancing and improving society productivity.
\end{abstract}

Kata Kunci: Silat, Identity, Education, Marital Art, Health

\begin{abstract}
Abstrak
Silat salah satu bentuk identitas seni beladiri Nusantara kebudayaan Indonesia berisi tentang pendidikan yang berkembang dalam masyarakat. Dalam dunia modern, silat bukan hanya sebagai alat seni bela diri tetapi berkembang menjadi sebuah upaya dalam memelihara kesehatan melalui olehraga. Silat berfungsi juga sebagai sarana pendidikan jasmani dan rohani melalui proses tahapan pendidikan berjenjang secara formal melalui peraturan yang dibuat masing-masing perguruan silat. Identitas merupakan bagian dari kebudayaan dan lingkungan sosial yang dapat bergeser sesuai dinamika kehidupan masyarakat. Identitas berkembang berdasarkan ruang dan waktu setiap generasi dalam dunia kehidupan sehari-hari yang berasal dari pikiran dan tindakan manusia dan berkembang menjadi praktek nyata. Pendidikan jasmani dan rohani yang ditanamkan melalui silat membentuk karakter bangsa yang tangguh, kuat dan berbudi luhur dan berkembang menjadi watak identitas bangsa. Tuntutan dunia modern, peran silat berkembang selain untuk menjaga diri juga menjadi salah satu sarana dalam upaya pemeliharaan kesehatan melalui bidang olahraga sehingga keseimbangan jasmani dan rohani merupakan salah satu jalan dalam meningkatkan produktivitas masyarakat.
\end{abstract}

Kata Kunci: Silat, Identitas, Pendidikan, Seni Beladiri, Kes ehatan

\footnotetext{
${ }^{1}$ Penulis adalah Mahasiswa Program Doktor Sosiologi-Antropologi Universitas Padjadjaran, Bandung

2 Pelatih Silat, Staf Pengajar Olahraga Yayasan Fathul Huda Bandung 


\section{A. PENDAHULUAN}

K ebudayaan dapat dikatakan merupa kan suatu sistem keteraturan dari makna dan simbol-simbol. Individuindividu dengan pengetahuan dan pengala mannya dapat mendefinisikan, mengekspre sikan perasaan-perasaan dan membuat penilaian selama proses waktu perkemba ngan kebudayaan. Hal ini merupakan suatu pola makna-makna yang ditransmisikan secara historis terkandung dalam bentukbentuk simbolik sehingga manusia dapat saling berkomunikasi, memantapkan, dan mengembangkan pengetahuan mereka mengenai dan bersikap terhadap kehidupan. Simbol-simbol kebudayaan itu memengaruhi kehidupan sosial sebagai hubungan satu arah dalam memberi informasi, pengaruh dan membentuk kebudayaan secara sosial dan normatif (Garna, 2008).

Kebudayaan juga merupakan suatu peralatan simbolik bagi pengontrol perilaku sehingga proses kebudayaan harus dipaha $\mathrm{mi}$, diterjemahkan dan diinterpretasi. Bahasa simbolik dari kebudayaan bersifat umum, fungsi simbolik universal dan manusia tidak dapat memahami kebudayaan suatu masyarakat tanpa fungsi ini. Interpretasi makna simbolik kebudayaan merupakan pemahaman dalam mengartikan sebuah simbol yang dihasilkan dari sebuah kegiatan. Sebagai contoh adalah bahasa sebagai ungkapan simbol dalam berkomu nikasi, selain bahasa, komunikasi manusia menggunakan tanda dan simbol dalam lukisan, tarian, musik, arsitektur, gerak-gerik, postur tubuh, perhiasan, pakaian, ritual, agama, kekerabatan dan lain-lain. Manusia dapat memberikan makna dan persepsi kepada setiap kejadian tindakan atau objek yang berkaitan dengan pikiran, gagasan dan emosi. (Geertz, The Interpretation of Culture, 1973).

Tindakan kebudayaan merupakan pedoman bagi kehidupan warga masyarakat tersebut dalam menjalani kehidupan. silat dapat merupakan salah satu simbol pedoman tindakan menjalani kehidupan yang tercermin dalam setiap gerakan. Tindakan berfungsi sebagai acuan untuk melakukan interpretasi lingkungan yang dihadapi, mendorong dan menghasilkan terwujudnya tindakan bermakna dalam menghadapi lingkungan (Garna, 2008). Tindakan bermakna pada silat merupakan suatu kajian filosofi yang mengkombinasikan antara warisan kebudayaan, identitas, latihan mental dan fisik. Suwaryo (2008) berpendapat bahwa pencak silat dapat diklarifikasikan ke dalam wujud kebudayaan yang berupa seni beladiri yang memiliki pola-pola tertentu dan memiliki adat tata kelakuan tersendiri. Pencak silat merupakan aktivitas manusia dalam masyarkat bersifat konkret, yang dapat di observasi.

Dalam sebuah pengetahuan lokal mengenai kebudayaan, kita dapat mema hami dengan mencoba menangkap apa yang kita pahami dari suatu prinsip-prinsip terbentuknya organisasi di sebuah masyarakat, bagaimana proporsi pembentu kannya, sehingga dapat muncul interpretasiinterpretasi dari sebuah kegiatan kebudayaan. (Geertz, Local Knowledge, 1983). Pengorganisasian merupakan se buah sarana dalam melaksanakan kegiatan kebudayaan selanjutnya karena dalam sebuah organisasi terkandung makna kepercayaan masyarakat kepada seorang tokoh dalam mengatur. Tokoh dengan dukungan masyarakat atau anggota dalam suatu organisasi merupakan suatu sarana dalam peningkatan silat sebagai warisan kebudayaan. Tokoh silat sebagai pembawa kebudayaan dianut masyarakat karena menghasilkan perilaku yang dapat membawa kebaikan pada masyarakat.

Sebuah interpretasi dapat disertai dengan sebuah penjelasannya. Sebuah penjelasan dapat beranjak dari perhatian kita terhadap institusi, cara kerjanya, gambaran, ucapan-ucapan, hal yang terlihat termasuk interaksi sosial yang terjadi termasuk pada upacara atau perayaan yang diadakan oleh suatu daerah, sehingga sebuah makna dalam menginterpretasi dapat disertai penjelasan sesuai dengan maksud kebudayaan yang tergambar dalam suatu tempat (Geertz, Local Knowledge, 1983). Interpretasi dari sebuah kebudayaan yang berwujud dalam silat tercermin dari karakter-karakter teknik yang dihasilkan menyesuaikan dengan lingkungan dan sifat karakter tersebut.

Beranjak dari penelitian yang sudah dilakukan oleh berbagai tokoh melalui paradigmanya, terdapat perkembangan yang ingin diketahui melalui suatu kebudayaan yaitu proses sosial dan budaya yang terjadi di suatu daerah. Suatu kebudayaan merupakan suatu turunan dari formasi-formasi organisasi sosial. Kerangka 
tersebut adalah kepercayaan, simbol-simbol dan nilai yang mengekspresikan perasaan, membuat peraturan yang merupakan interaksi antara perilaku-perilaku dan berkembang diikuti dalam suatu organisasi sosial. Kebudayaan dan sosial struktur adalah dua maksud berbeda meskipun ditinjau dari satu fenomena yang sama. Yang satu merupakan perilaku sosial yang menghormati maksud dan memelihara perilaku tersebut dan yang lainnya berkontribusi pada pelaksanaan fungsifungsi tersebut (Geertz, The Interpretation of Culture, 1973)

Dalam sejarah perkembangan manusia, kebudayaan tidak terlepas dari isu identitas yang merupakan pengusung dari kebudayaan. Isu identitas dipandang seba gai sesuatu yang statis dan cenderung given. Seiring perkembangan jaman di ma sa modern yang serba kompleks maka terjadi pergeseran bahwa identitas lebih bersifat dinamis yaitu dapat dibentuk, dikonstruksi, tidak stabil dan dapat dimodifikasi.

Identitas dapat dibentuk oleh ras, etnik, kasta, latar belakang, gender, hubungan kekerabatan, agama bahkan kelas dan semuanya terangkum dibawah sebuah kekuasaan atau negara yang semuanya dapat tergantung dari negara untuk mengaktifkannya. Identitas seseorang merupakan sebuah tanda, baik pribadi maupun bagi kelompok besarnya menjadi ciri khas membentuk sebuah perilaku. Identitas tidak dapat dikatakan mutlak, tidak diberikan hanya sekali dan untuk semua (Maalouf,2000:23). Hal ini mendukung kajian bahwa identitas bersifat dinamis dan tidak ada yang asli dan berbaur (Maalouf, 2000:24).

Identitas akan mengalami wujud dan interpretasi dari masyarakat pengusung identitas yang bersangkutan dalam mengha dapi pengaruh luar dan seringkali terkait kepentingan nasional bahkan internasional. Masyarakat sering melupakan hakekat keberadaan identitas dalam kehidupan berbangsa di tengah perubahan-perubahan baik nasional maupun global. Identitas merupakan hasil konstruksi sosial, sesuatu yang diciptakan, berproses, membentuk apa yang kita pikir dari sudut situasi masa lalu dan masa kini, harapan dan lintasan ke depan, membentuk konstruksi identitas.
Identitas hadir dalam menjawab sejumlah pertanyaan kritis. Individu dan agen berusaha mengkonstruksi suatu narasi identitas koheren dimana diri membentuk suatu lintasan perkembangan dari masa lalu sampai masa depan yang dapat diperkirakan (Giddens, 1991:75), jadi identitas bukanlah hanya dimiliki individu tetapi dipahami secara refleksif oleh orang dalam konteks biografinya (Giddens, 1991 :53). Dalam kajian identitas, berdasarkan teori realita sosial, Berger dan Luckman (1995:87) menyebutkan tiga proses dalam mengkaji konstruksi identitas dalam suatu kelompok dan masyarakat, terdiri dari :

1) Eksternalisasi (penyesuaian diri dengan dunia sosio kultural). Eksternalisasi merupakan proses dialetika dimana individu secara kolektif dan perlahanlahan mengubah pola-pola dunia obyektif secara bersama-sama dan membentuk dunia baru. Pada proses ini dapat dikatakan sebagai tahap awal seorang individu beradaptasi dan mengenal masyarakat atau kelompok terkait dengan sistem nilai, norma, dan struktur yang ada didalamnya.

2) Obyektivasi (interaksi sosial dengan dunia sosio kultural). Obyektivasi merupakan proses dimana seorang individu seakan-akan sebagai sesuatu yang obyektif dengan adanya proses penarikan realita keluar dari individu tersebut. Dalam proses ini interaksi sosial yang terjadi merupakan proses penyadaran akan posisi diri di dalam masyarakat atau kelompok.

3) Internalisasi (pendefinisian diri individu dengan dunia sosio kultural). Interna lisasi merupakan proses dimana terjadi penarikan kembali dunia sosial yang terobyektivasi ke dalam diri manusia. Pada tahapan ini, seorang individu mengalami proses identifikasi diri terkait adanya penggolongan sosial yang ada di dalam masyarakat atau kelompok. Identifikasi diri yang terjadi tersebut berdasarkan pemahaman, kesadaran, dan identifikasi identitas individu terhadap masyarakat atau kelompoknya.

Setelah terbentuk identitas dari masingmasing kelompok dan masyarakat, maka Berger dan Luckman (1995:68-187) membedakan dua konsep mengenai 
masyarakat. Kedua konsep masyarakat tersebut terdiri dari :

1) Masyarakat sebagai Realitas Obyektif yang berarti bahwa adanya eksitensi dalam realitas sosial dalam hubungan yang ada pada lembaga-lembaga sosial. Eksistensi manusia terwujud dalam sebuah produk dari kegiatan manusia. Budaya merupakan produk manusia hasil dari hubungan timbal balik antara manusia dengan lingkungan. Hubungan timbal balik lainnya antara manusia dengan tatanan budaya dan sosial yang dihubungkan melalui perantara aktoraktor yang menjaganya (significant others). Selanjutnya hubungan timbal balik tersebut akan membentuk jati diri manusia (human self). Adanya proses eksternalisasi menghasilkan dunia yang obyektif. Obyektivasi dalam hal ini merupakan proses penataan pemak naan terkait perangkat bahasa dan kognitif sebagai suatu kenyataan. Dalam proses sosialisasi, perangkat bahasa dan kognitif diinternalisasikan kembali sebagai kebenaran yang obyektif (Berger, 1995:71).

2) Masyarakat Sebagai Realitas Subyektif terjadi karena adanya proses-proses dialetika terkait eksternalisasi, obyek tivasi, dan internalisasi menjadi tuntutan proses yang terjadi dalam suatu kelompok atau masyarakat. Ketiga proses tersebut terjadi secara terus menerus dan tidak dapat dipisahkan dari masyarakat. Melalui ketiga proses tersebut masyarakat dapat di lihat secara obyektif dan subyektif.

Manusia sebagai individu memiliki kecenderungan ke arah sosialitas yang membutuhkan pengakuannta dalam anggota masyarakat. Keberadaan manusia menjadi anggota dalam suatu masyarakat atau kelompok membawa dirinya memiliki identitas yang diakui.

Identitas adalah kesadaran akan sifat khas diri sendiri, golongan sendiri, komunitas sendiri, atau negara sendiri (Koentjaraningrat, 2003:84). R. Racliffe Brown beranggapan identitas dimaknai sebagai sesuatu yang ada pada individu dalam suatu masyarakat yang terwujud karena adanya kebiasaan dan kepercayaan sehingga menciptakan fungsi tertentu untuk melestarikan struktur (Mahendra, 2013). Keberadaan struktur tidak lepas dari adanya sistem sosial yang ada pada suatu kelompok atau masyarakat. Menurut Giddens sistem sosial merupakan hasil dari perbuatan manusia (aktor) yang saling berhubungan dan terpola dengan ruang dan waktu, kemudian terbentuk sebuah struktur yang lengkap (Kinasih, 2009:103).

Banyak hal terkait isu identitas. Silat merupakan salah satu ciri dari identitas budaya, sebuah isu identitas yang terkait dengan seni beladiri. Nenek moyang bangsa Indonesia telah memiliki cara pembelaan diri yang ditujukan untuk melindungi dan mempertahankan kehidupan nya atau kelompoknya dari tantangan alam (Gilang, 2007). Bela diri diciptakan dengan menirukan gerakan binatang yang ada di alam sekitarnya, seperti gerakan kera, harimau, ular atau burung. Selain itu, perkembangan identitas silat sebagai warisan kebudayaan mengadopsi teknikteknik lainnya tidak hanya yang terdapat dari Nusantara, tetapi terjadi proses asimilasi dari teknik-teknik mancanegara lainnya seperti dari Negara Cina dan beladiri Eropa lainnya.

Asal mula ilmu bela diri di nusantara ini kemungkinan juga berkembang dari keterampilan suku-suku asli Indonesia dalam berburu dan berperang dengan menggunakan parang, perisai, dan tombak dengan memanfaatkan benda-benda sekeliling (Alexander., etc, 1972). Bela diri tersebut berfungsi sebagai pembelaan diri terutama serangan dari binatang buas dan serangan kelompok lain dalam mempere butkan bahan makanan.

Silat diperkirakan menyebar di kepulauan nusantara semenjak abad ke-7 masehi, akan tetapi asal mulanya belum dapat ditentukan secara pasti. Kerajaankerajaan besar, seperti Sriwijaya dan Majapahit disebutkan memiliki pendekarpendekar besar yang menguasai ilmu bela diri dan dapat menghimpun prajurit-prajurit yang kemahirannya dalam pembelaan diri dapat diandalkan. Penelitian Donald F. Draeger membuktikan adanya seni bela diri bisa dilihat dari berbagai artefak senjata yang ditemukan dari masa Hindu-Budha serta pada pahatan relief-relief yang berisikan sikap-sikap kuda-kuda silat di candi Prambanan dan Borobudur. Masyarakat Indonesia kala itu memakai senjata dan seni beladiri silat adalah tak terpisahkan, bukan hanya dalam olah tubuh 
saja, melainkan juga pada hubungan spiritual yang terkait erat dengan kebudayaan Indonesia. (Draeger, 1992). Selain itu, hubungan perdagangan dan kerjasama Indonesia dengan negara lain memberikan pengaruh ilmu bela diri dari Cina dan India dalam silat. Hal ini terjadi sejak awal kebudayaan Melayu telah mendapat pengaruh dari kebudayaan yang dibawa oleh pedagang maupun perantau dari India, Cina maupun Eropa, sehingga teknik silat nusantara sangat berkembang dan banyak dipengaruhi oleh berbagai Negara pendatang yang disesuaikan dengan kondisi masyarakat Indonesia pada masa itu.

Dalam masyarakat majemuk di Indonesia, pembauran terjadi dalam kebuda yaan Indonesia, begitupun dengan perkembangan silat di Indonesia. Profil pencak silat di Indonesia dapat dikelompokkan ke dalam tiga bagian yaitu:

1) Pencak silat asli (original), ialah pencak silat yang berasal dari lokal dan masyarakat etnis di Indonesia.

2) Pencak silat bukan asli yang sebagian besar berasal dari Kung Fu, Karate dan Jujitsu.

3) Pencak silat campuran, ialah campuran antara pencak silat asli dan bukan asli (beladiri asing yang ingin bergabung dengan nama pencak silat sesuai peraturan $A D$ dan ART IPSI) (Kumaidah, 2012).

Kini pencak silat telah merambah masuk dalam dunia pendidikan. Di berbagai sekolah dari tingkat SD sampai Perguruan Tinggi, Pencak Silat menjadi bagian dari kegiatan ekstra kurikuler yang banyak di gemari. Bahkan Pencak Silat telah menjadi salah satu cabang olahraga yang ditandingkan dalam berbagai kejuaraan baik tingkat nasional sampai tingkat dunia. Jika keempat aspek tersebut dapat dipadukan dalam diri pesilat, sudah barang tentu akan menjadi salah satu unsur perekat bangsa untuk bersatu dan mengangkat harkat, derajat, dan martabat bangsa Indonesia di mata dunia. Penelitian Wilson menghasilkan bahwa seni bela diri Indonesia bernama Pencak Silat merupakan sarana budidaya tubuh, wahana pengembangan spiritual, seni pertunjukan, dan olahraga internasional dan sejarahnya terkait erat dengan munculnya negara Indonesia. Silat dapat dijelaskan melalui ilmu pengetahuan, pedagogi Pencak Silat, kekuatan tubuh maupun warisan nenek moyang termasuk pengelolaan tradisi; dari mistis ke molekul; dan badan berdaulat dan praktis kekuasaan (Wilson, 2015). Pedagogi silat merupakan bagian dari sebuah proses belajar. Belajar adalah suatu proses yang kompleks dan terjadi pada diri setiap orang sepanjang hidupnya. Proses belajar itu terjadi karena adanya interaksi antara seseorang dengan lingkungannya. Oleh karena itu, belajar dapat terjadi dimana saja dan kapan saja. Salah satu tanda seseorang telah belajar adalah adanya perubahan tingkah laku pada diri seseorang tersebut yang mungkin disebabkan oleh terjadinya perubahan pada tingkat pengetahuan, keterampilan, atau sikapnya (Arsyad, 2007:1). Pembelajaran dalam silat membentuk karakter disiplin dan peningkatan fisik, maka setelah terjadinya proses belajar silat, kemampuan disiplin dan fisik dapat terlihat berkembang.

Penelitian de Castella menunjukkan bahwa silat dapat membangun harga diri, mengajarkan bagaimana menangani oposisi dan agresi. Banyak anak-anak tidak pernah melihat seseorang yang kuat secara fisik yang memilih untuk tidak menggunakannya dengan cara kekerasan (de Castella, 2006), hal ini menandakan bahwa seni beladiri silat tidak hanya membangun secara fisik tetapi membangun mental yang sehat. Beladiri silat bergerak mengikuti gerak tubuh alami, lentur dan lembut. Kekuatan fisik dan mental diajarkan bertahap sejak awal latihan sampai mencapai tingkatan tertinggi, begitupula simbol-simbol gerakan bermakna bahwa semakin tinggi tingkatan maka semakin bijaksana (Alexander, 1972). Dari beberapa penelitian yang sudah dilakukan, bahwa dalam silat terdapat makna filosofi yang tinggi dalam membentuk karakter manusia dan memfungsikan silat sebagai peningkat unsur fisik, mental dan spiritual.

Dalam prakteknya, seni beladiri silat merupakan symbol dari 4 makna yang bertujuan membangun produktivitas masya rakat. Produktivitas ini dibangun saling berkesinambungan dan konsisten. Terdapat 4 aspek utama dalam kegiatan silat, yaitu:

1) Aspek Mental Spiritual : Pencak silat membangun dan mengembangkan kepri badian dan karakter mulia atau karakter tingkat tertinggi seseorang. Para 
pendekar dan maha guru pencak silat zaman dahulu untuk mencapapai tingkatan tertinggi harus melewati tahapan semadi, tapa, atau aspek kebatinan lainnya disesuaikan dengan masa kepercayaan pada saat itu untuk mencapai tingkat tertinggi keilmuannya.

2) Aspek Seni Budaya : Budaya dan permainan seni pencak silat ialah salah satu aspek yang sangat penting. Istilah Pencak pada umumnya meng gambarkan bentuk seni tarian pencak silat, dengan musik dan busana tradisional. Hal ini dimaksudkan agar silat dapat digemari masyarakat dan bersifat menyenangkan untuk dipelajari. Tidak terdapat unsur kekerasan tetapi dapat meningkatkan kemampuan fisik dan mental seseorang tercermin dari hasil silat yang berfungsi sebagai seni budaya.

3) Aspek Bela Diri : Kepercayaan dan ketekunan diri sangat penting dalam menguasai ilmu bela diri dalam pencak silat. Istilah silat, cenderung mene kankan pada aspek kemampuan teknis bela diri pencak silat. Kemampuan teknis ini tercipta dari perpaduan unsur budaya, lingkungan dan seni yang diciptakan pendiri pencak silat dan menyesuaikan dengan karakter dari teknik itu sendiri. Teknik tercipta sesuai karakternya sehingga pemahaman dan penghayatan pada karakter tersebut dapat menghasilkan suatu ilmu beladiri silat yang baik.

4) Aspek Olah Raga: Ini berarti bahwa aspek fisik dalam pencak silat sangatlah penting. Pesilat mencoba menyesuaikan pikiran dengan olah tubuh. Olahraga dalam silat merupakan tujuan utama dalam meningkatkan kondisi fisik seseorang. Kompetisi ialah bagian as pek ini yang bertujuan memupuk semangat dalam meningkatkan prestasi silat melalui olahraga. Aspek olahraga silat bukan hanya dapat bermanfaat bagi pribadi pesilat namun juga bermanfaat membawa nama baik daerah bahkan internasional. Aspek olahraga meliputi pertandingan dan demonstrasi bentuk-bentuk jurus, baik untuk tunggal, ganda atau regu yang dipertontonkan pada masyarakat umum nasional maupun masyarakat inter nasional. (Subroto dan Rohadi, 1996:6).
Di Indonesia, organisasi pencak silat berada di bawah Komite Olahraga Nasional Indonesia (KONI). Dalam mengembangkan peranan pencak silat, dibentuklah organisasi khusus pencak silat bersifat nasional, yang dapat pula mengikat aliran-aliran pencak silat di seluruh Indonesia. Pada tanggal 18 Mei 1948, terbentuklah Ikatan Pencak Silat Indonesia (IPSI). Kini IPSI tercatat sebagai organisasi silat nasional tertua di dunia. Pada 11 Maret 1980, Persatuan Pencak Silat Antarbangsa (Persilat) didirikan atas prakarsa Eddie M. Nalapraya (Indonesia), yang saat itu menjabat ketua IPSI.

Setiap empat tahun di Indonesia ada pertandingan pencak silat tingkat nasional dalam Pekan Olahraga Nasional. Pencak silat juga dipertandingkan dalam SEA Games sejak tahun 1987. Dalam olahraga beladiri pencak silat jika dilihat dari lamanya waktu bertanding proses yang terjadi merupakan kegiatan olahraga yang bersifat aerobic dan anaerobik secara massif. Lamanya waktu bertanding mulai 40 detik sampai 4-5 menit (Bouchard C. dkk, 1975: 92). Akan tetapi jika dilihat dari proses latihan sebagai persiapan pertan dingan, maka kegiatan latihan berlangsung antara $90-120$ menit dan kegiatan tersebut terutama bersifat aerobik. Hal ini merupakan suatu proses latihan dalam meningkatkan cara kerja jantung dan paru.

Di tingkat nasional olahraga melalui permainan dan olahraga pencak silat menjadi salah satu alat pemersatu nusantara, bahkan untuk mengharumkan nama bangsa, dan menjadi identitas bangsa. Olahraga pencak silat sudah dipertandingkan di skala internasional. Di Indonesia banyak sekali aliran-aliran dalam pencak silat, dengan banyaknya aliran ini menunjukkan kekayaan budaya masyarakat yang ada di Indonesia dengan nilai-nilai yang ada di dalamnya.

Bila di kaji lebih dalam, maka gerakan-gerakan silat merupakan seni olah tubuh yang bermanfaat dan merupakan bagian dari olahraga. Silat merupakan gabungan dari aspek bela diri dan olahraga, baik fisik maupun pernapasan. Keterpa duan ini menjadikan silat sebagai tradisi yang dipahami oleh seluruh lapisan masyarakat dunia dan menjadi terkenal di Eropa. Dalam masyarakat modern seka rang, seni pengembangan beladiri silat disesuaikan dengan kebutuhan dan tuntutan 
masyarakat terutama dalam pemeliharaan kesehatan melalui olahraga.

Bergerak atau beraktifitas fisik adalah setiap gerakan tubuh yang mening katkan pengeluaran tenaga dan energi kalori. Olahraga merupakan suatu bentuk aktifitas fisik yang terencana dan terstruktur yang melibatkan gerakan tubuh secara berulang-ulang dan ditujukan untuk meningkatkan kebugaran jasmani. Sehat adalah keadaan badan sejahtera dari badan , jiwa, dan sosial yang memungkinkan setiap orang hidup produktif secara sosial dan ekonomi. Bugar adalah keadaan tubuh melakukan kegiatan sehari-hari tanpa menimbulkan kelelahan fisik dan mental yang berlebihan.

Kesehatan Olahraga terdapat dalam Undang-undang Kesehatan No. 36 Tahun 2009 Pasal 80 (1) Upaya kesehatan olahraga ditujukan untuk meningkatkan kesehatan dan kebugaran jasmani masyara kat. (2) Peningkatan derajat kesehatan dan kebugaran jasmani masyarakat sebagai mana dimaksud pada ayat (1) merupakan upaya dasar dalam meningkatkan prestasi belajar, kerja, dan olahraga. (3) Upaya kesehatan olahraga sebagaimana dimaksud pada ayat (1) dilaksanakan melalui aktifitas fisik, latihan fisik, dan/atau olahraga.

Dalam Pasal 81 (1) Upaya kesehatan olahraga lebih mengutamakan pendekatan preventif dan promotif, tanpa mengabaikan pendekatan kuratif dan rehabilitatif. (2) Penyelenggaraan upaya kesehatan olahraga diselenggarakan oleh Pemerintah, pemerintah daerah, dan masyarakat.

Olahraga merupakan gaya hidup dalam meningkatkan derajat kesehatan. Aktifias fisik seperti olahraga merupakan cara dalam menurunkan angka kejadian penyakit tidak menular seperti diabetes, jantung, stroke dan darah tinggi. Penelitian Rusmana Tahun 2002 memperlihatkan bahwa tidak merokok, berolahraga secara teratur dan melakukan kerja fisik berpeluang lima kali lebih tinggi terhindar dari penyakit jantung dan stroke, sehingga pengaruh olahraga dalam menurunkan angka kejadian penyakit tidak menular mempe roleh hasil yang signifikan (Kemenkes, 2006). Keteraturan gerak dalam olahraga silat dapat meningkatkan asupan oksigen dalam otak dan anggota tubuh lainnya sehingga tubuh akan selalu bugar dan menurunkan risiko terjadinya penyakit tidak menular terutama akibat gaya hidup yang salah.

Olahraga merupakan bagian dari relasi sosial masyarakat. Relasi ini dapat meningkatkan citra dan semangat masyara kat dalam meningkatkan peran olahraga sebagai sarana meningkatkan derajat kesehatan. Relasi sosial dalam olahraga merupakan implementasi dalam mengingka tkan kualitas manusia secara sosial dan psikologi di masyarakat.

Silat dapat menjadi peran dalam relasi sosial. Praktek pelaksanaan silat dilakukan berkelompok mulai dari tingkatan dasar, sebelum dan sesudah latihan, relasi sosial dibangun berawal dari pemaknaan setiap gerakan dalam latihan.

Perisai diri merupakan salah satu hasil budaya seni beladiri Indonesia yang berperan dalam pembangunan kualitas manusia dan meningkatkan produktivitas masyarakat melalui olahraga seni beladiri. Perkembangan Seni Beladiri Silat Perisai Diri berkembang ke seluruh Indonesia sampai mancanegara, mulai dari perkampungan, kelompok-kelompok sosial masyarakat, pendidikan dasar sampai akademisi. Hal ini menandakan bahwa silat dapat diterima oleh segala kalangan masyarakat berdasarkan manfaat yang diterima baik secara fisik maupun mental.

Tujuan dari makalah ini adalah untuk membahas arti dari simbol-simbol olahraga silat sebagai bagian dari hubungan sosial dengan mengambil salah satu perguruan silat Perisai Diri sebagai Seni beladiri Indonesia. Simbol dan makna adalah kajian khusus yang terjadi di masyarakat Bandung terkait dengan perbedaan makna identitas berbagai generasi melalui beladiri silat sebagai sarana peningkatan kualitas jasmani dan rohani masyarakat yang berdampak pada kesehatan, sangat berpengaruh pada berfungsinya komunitas sosial dan psikologis untuk diimplementasikan. 


\section{B. METODE PENELITIAN}

M etode penelitian yang diambil adalah metode kualitatif dengan kajian etnografi untuk memahami suatu pandangan hidup dari sudut pandang penduduk setempat. (Spradley, 2007:3). Tujuan penggunaan metode etnografi dalam penelitian ini dimaksudkan untuk mengana lisis perilaku nyata budaya yang berhubungan dengan perilaku masyarakat dan memahami bahwa silat sebagai identitas dalam perbedaan generasi dalam menjalani beladiri silat. Dasar pertimbangan peneliti menggunakan metode etnografi adalah:

1) Penelitian adalah meneliti tentang kebudayaan dari kelompok yang berkebudayaan sama.

2) Peneliti mencari berbagai pola ritual, perilaku sosial, adat istiadat atau kebiasaan.

3) Kelompok kebudayaan tersebut telah lengkap dan berinteraksi dalam waktu yang cukup lama.

4) Menggunakan teori untuk menemukan pola dan kelompok budaya yang sama dimana peneliti terlibat secara langsung dalam kerja lapangan yang lama.

5) Dalam menganalisa data peneliti bersandar pada pandangan dari pada partisipan.

6) Analisa data menghasilkan pemahaman tentang bagaimana kelompok berkebudayaan yang sama berjalan, berfungsi dan cara hidup (Creswell, 2014:127-129).

Penelitian menggunakan wawanca ra dan observasi terkait makna identitas budaya dalam mengembangkan relasi sosial melalui beladiri silat sebagai sarana dalam meningkatkan pendidikan jasmani dan rohani yang berdampak pada pemeliharaan kesehatan.

\section{HASIL DAN PEMBAHASAN}

1. Gambaran Umum

D erisai Diri didirikan oleh Raden Mas Soebandiman Dirdjoatmodjo di Surabaya tanggal 02 Juli 1955. Pada tanggal 06 Juni 1965, Perisai Diri di bawa ke Bandung dan di dirikan di SMAN 2 oleh Oktav Bayu Dirgantara dan di ITB oleh Ir. Both Soedargo. Ketua Pusat Perisai Diri sekarang dipimpin oleh Dwi Sucipto.

Oktav Bayu Dirgantara merupakan salah satu tokoh silat yang dapat membawa silat sampai ke mancanegara melalui kemampuannya dalam menjelaskan silat dari perspektif ilmu pengetahuan, sosial dan budaya, sehingga silat dapat diterima dan diikuti oleh bangsa Eropa.

Terdapat 13 tahap tingkatan sejak tingkatan dasar 1 sampai tingkatan pende kar. Pendekar yang diangkat semasa pendiri Perisai Diri masih hidup disebut pendekar historis dan masih terdapat beberapa orang pendekar historis yang masih hidup yaitu Bambang Sukotjo dari Bandung.

Perisai diri memiliki prosedur selama latihan yang terdapat dalam Tatacara Latihan , terdiri dari :

1) Hening Pembuka

2) Pembacaan Janji Perisai Diri

3) Salam Bunga Sepasang

4) Pelaksanaan Latihan

5) Hening Akhir

6) Salam Akhir Inti sari ilmu silat yang dikembang kan Raden Mas Soebandiman Dirdjoat modjo terdiri dari 19 teknik, yang disesuaikan dengan kebutuhan dan anatomi manusia. Ke-19 teknik tersebut dibagi dalam 2 kategori, yaitu :

1) Teknik Asli terdiri dari 14 bagian yaitu :

(1) Burung Meliwis

(2) Satria Hutan

(3) Burung Kuntul

(4) Putri Bersedia

(5) Burung Garuda

(6) Putri Berhias

(7) Harimau

(8) Putri Teratai

(9) Naga

(10)Putri Sembahyang

(11)Satria

(12)Linsang

(13)Kuda Kuningan

(14)Pendeta

2) Teknik Kombinasi terdiri dari 5 bagian yaitu :

(1) Minangkabau

(2) Cimande

(3) Betawen

(4) Bawean

(5) Jawa Timuran

Masing-masing teknik tersebut mempunyai ciri khas dalam hal pengosongan, peringanan dan pemberatan tubuh, gerak merampas dan merusak, menangkis dan mengunci, cara menghindar dan mengelak, gerak melompat, cara 
menolak, menebang dan melempar, mendorong dan menebak, serangan tangan, kaki dan badan, pengaturan nafas, penyaluran tenaga, serta pengaturan senja ta.

Teknik asli dipadukan dengan teknik-teknik senjata. Dalam Perisai Diri, mengajarkan cara menggunakan senjata. Senjata wajib bagi pesilat Perisai Diri adalah pisau, pedang dan toya. Pemakaian senjata wajib mulai dari tingkatan keluarga. Dengan dasar penguasaan ketiga senjata itu, pesilat Perisai Diri dapat menggunakan senjatasenjata lainnya, seperti pentungan, rantai, teken, clurit, kipas, trisula, golok, katana, dan sebagainya.

Sebagai pengikat dan komitmen dalam berperilaku dalam kehidupan seharihari, Perisai Diri memiliki janji yang wajib diucapkan dan dilaksanakan oleh setiap anggota. Adapun janji Perisai Diri yaitu :

1) Berketuhanan Yang Maha Esa

2) Setia dan taat kepada Negara

3) Mendahulukan kepentingan Negara

4) Patuh kepada perguruan

5) Memupuk rasa kasih sayang

Keseluruhan rangkaian latihan silat dalam Perisai Diri memadukan antara teknik olah tubuh dan mental berdasarkan kepada ilmu yang diwariskan oleh pendirinya. Silat perisai diri bukan hanya sebagai warisan budaya bangsa, tetapi sebagai sarana kedisiplinan dalam meningkatkan kualitas sumber daya manusia Indonesia.

\section{Hasil penelitian}

$\mathrm{B}$ andung merupakan ibu kota provinsi dan memiliki gaya hidup modern sebagai kota urban. Perkembangan kota Bandung menjadikan budaya baru Indonesia yaitu sebuah budaya urban pada umumnya (van Klinken \& Berenschot, 2014: 17). Gaya hidup yang membutuhkan kecepatan dan ketepatan dalam meningkat kan produktivitas. Silat dapat menjadi salah satu solusi dalam meningkatkan produktivi tas melalui olah raga beladiri yang bukan hanya bermanfaat sebagai olah raga tetapi bermanfaat dalam melindungi diri terutama hidup di kota besar seperti Bandung.

Penelitian mengenai manfaat bagi pembelaan diri yang dilakukan di Kabupaten Banjarnegara menunjukkan bahwa kebera daan perguruan-perguruan pencak silat yang ada di Kabupaten Banjarnegara memiliki peran besar dalam meminimalisir kejahatan di sekitar wilayah tersebut (Suwaryo, 2008: 73-78). Peran tersebut bukan hanya dalam penanganan kejahatan tetapi juga perilaku yang dihasilkan pesilat dapat melindungi masyarakat bukan hanya sebagai seni beladiri saja.

Para peneliti dalam seni dan ilmuilmu sosial menyoroti sentralitas pencak silat antara kesenian Asia Tenggara dalam membandingkan seni pertunjukan tradisional dan modern. Studi tentang gerakan berdasarkan atau terkait dengan silat dan musik merupakan suatu kesatuan aliran yang sulit diterangkan dengan logika karena tubuh sudah sedemikian menerima aliran gerakan dalam silat (Paetzold, 2016). Silat dilakukan secara bertahap melalui beberapa tahap, dari mulai tahap gerakan sederhana sampai dengan gerakan kompleks yang saling berkesinambungan antara teknik dan pernafasan. Gerakan silat pada tahap akhir merupakan gerakan tertinggi dan sangat lentur dan halus, tetapi bukan hanya dari gerakan saja tetapi perilaku dalam kehidupan sehari-hari harus mengikuti sesuai dengan tahapan silat yang sudah ditempuh.

Silat perisai diri memiliki beberapa fungsi dalam kehidupan masyarakat. Fungsi pertama bahwa silat dipandang sebagai identitas budaya, bahwa seni bela diri perisai diri didirikan oleh orang Indonesia asli yang menempuh pendidikan silat baik pada guru-guru lokal maupun berguru pada pesilat asing yang berasal dari Tiongkok yaitu Yap Kie San, sehingga tampak akulturasi budaya dalam teknik silat yang dihasilkan untuk memperkaya khasanah teknik silat itu sendiri.

Fungsi kedua bahwa silat perisai diri dipandang dari segi pendidikan bermakna bahwa dalam setiap pengajaran terdiri dari beberapa tahap sebagai pembentuk kedisiplinan bagi anggota-anggotanya. Pendidikan jasmani dan rohani diberikan dan setiap akhir pertemuan, diberikan bekal spiritual tanpa memandang suku, agama, ras dan kepercayaan anggota sehingga Pendidikan spiritual lebih menekankan kepada perbaikan moral dan ketaatan pada Tuhan Yang Maha Esa. Pendidikan jasmani disesuaikan dengan tahapan tingkatan anggota baik tingkatan jenjang kecakapan 
silat maupun jenjang usia karena anggota dapat terdiri dari anak usia dini, remaja, dewasa bahkan lansia. Beban latihan fisik disesuaikan agar manfaat olahraga dapat dirasakan oleh seluruh anggota. Terakhir adalah fungsi pendidikan mental yang menekankan kekuatan jiwa dalam menempuh kehidupan lebih baik, tidak mudah menyerah dan putus asa. Pelajar dan mahasiswa dapat bertanggung jawab kepada pendidikannya agar berprestasi dan menjadikan silat sebagai sarana dalam menunjang kemajuan akademis di sekolah.

Fungsi ketiga adalah silat sebagai seni bela diri yang mendukung pada pemeliharaan diri dari pengaruh-pengaruh luar yang tidak menguntungkan baik secara fisik, mental maupun spiritual. Seni bela diri dapat dipakai dalam kehidupan sehari-hari dalam meningkatkan keberanian dan kemandirian selain teknik beladiri yang dapat memberikan kepuasan bagi pelakunya dalam mengelola tubuhnya. Seni beladiri adalah seni yang dapat dinikmati melalui indera penglihatan, sehingga keberagaman teknik beladiri dapat disajikan sebagai bagian dari upacara-upacara peringatan dalam menambah khasanah budaya Indonesia. Seni beladiri Perisai Diri menempatkan silat sebagai seni dan beladiri atau dalam istilah yang umum adalah pencak silat.

Pencak silat berasal dari dua kata yaitu pencak dan silat. Pencak berarti gerak dasar beladiri yang terikat pada peraturan. Silat berarti gerak beladiri sempurna yang bersumber pada kerohanian. Istilah silat dikenal secara luas di Asia Tenggara, akan tetapi di Indonesia istilah yang digunakan adalah pencak silat. Istilah ini digunakan sejak 1948 untuk mempersatukan berbagai aliran seni beladiri tradisional yang berkembang di Indonesia. Nama pencak digunakan di Jawa, sedangkan silat digunakan di Sumatera, Semenanjung Malaya, dan Kalimantan. Dalam perkem bangannya kini 2 istilah pencak lebih mengedepankan unsur seni dan penampilan keindahan gerakan, sedangkan silat adalah inti ajaran beladiri dalam pertarungan. Maryono (1999) menyimpulkan bahwa yang menjadi kriteria untuk membedakan arti Pencak dan arti Silat adalah apakah sebuah gerakan itu boleh dipertontonkan atau tidak.

Pengurus Besar IPSI pada tahun 1975 mendefinisikan pencak silat sebagai berikut: "Pencak silat adalah hasil budaya manusia Indonesia untuk membela, mempertahankan eksistensi (kemandirian nya) dan integritasnya (manunggal) terhadap lingkungan hidup/alam sekitarnya untuk mencapai keselarasan hidup guna meningkatkan iman dan taqwa kepada Tuhan Yang Maha Esa". Tokoh-tokoh pendiri IPSI (Ikatan Pencak Silat Indonesia) telah sepakat untuk tidak membedakan pengertian Pencak dengan Silat karena kedua kata tersebut memang mempunyai pengertian yang sama. Kata Pencak maupun Silat sama-sama mengandung pengertian kerohanian, irama, keindahan, kiat maupun praktek, kinerja, atau aplikasinya (Kumaidah, 2012).

Fungsi keempat adalah sebagai sarana pemeliharaan kesehatan baik fisik maupun jiwa. Pemilihan gaya hidup sehat melalui olahraga silat masih digemari baik oleh anak-anak, remaja dan dewasa. Setiap kelas usia, mempunyai tujuan berbeda dalam memilih silat. Penekanan pada olah raga, kekuatan fisik dan mental juga bermain sambil belajar, lebih ditujukan pada anak-anak dan remaja dalam menyalurkan energinya. Silat membuat aliran oksigen menjadi lancar sehingga anak-anak dan remaja yang mengikuti silat dapat juga berprestasi secara akademik di sekolah. Selain sarana fisik, sarana peningkatan kesehatan jiwa melalui silat dapat diaktifkan dari peran-peran organisasi sosial kemasyarakatan. Silat bukan hanya seba gai sarana pemeliharaan kesehatan tetapi juga fungsi sosial dalam bergaul dan saling bertukar informasi mengenai pemeliharaan kesehatan itu sendiri. Oleh karena itu, silat Perisai Diri menamakan organisasinya sebagai Keluarga Silat Nasional Indonesia yang berarti bahwa organisasi ini merupakan satu keluarga yang saling memberikan kebaikan dan kemajuan bagi sesama anggotanya, saling membantu dan melakukan kegiatan sosial kemasyarakatan sebagai langkah kepeduliannya bagi lingkungan.

Keberadaan peran sosial ini yang pada akhirnya membuat setiap anggota yang merupakan bagian dari masyarakat. Peran sosial anggota Keluarga Silat Nasional Indonesia Perisai Diri tercermin pada komitmen dan prestasi sesuai keberadaannya. Pelajar berprestasi dalam pendidikannya dan pegawai berprestasi 
dalam pekerjaannya. Ketaatan dan kedisipli nan yang di dapat di tempat latihan dipraktekan dalam kehidupan sehari-hari di lingkungan keluarga dan masyarakatnya.

\section{UCAPAN TERIMA KASIH}

1) Lembaga Pengelola Dana Pendidikan (LPDP) Kementerian Keuangan RI

2) Pengurus Perisai Diri Pengda Jabar dan Cabang Bandung

\section{E. PENUTUP}

- ebagai salah satu warisan budaya, 1 maka silat sebagai identitas budaya, - sarana pendidikan, seni beladiri dan praktek pemeliharaan kesehatan melalui olahraga memiliki beberapa simpulan antara lain :

1) Aktifitas Silat merupakan simbol pemaknaan identitas budaya melalui pendidikan untuk pemeliharaan kesehatan dan kemandirian.

2) Aktifitas silat hakekatnya merupakan sebuah sarana pengikat kebersamaan untuk melaksanakan tujuan yang sama.

3) Keberagaman dalam memahami teknik silat yang disesuaikan dengan perkem bangan kebutuhan masyarakat tidak menghilangkan budaya tersebut sehing ga tetap diakomodir sesuai dengan pemahaman dan kebutuhan masingmasing.

4) Kekuatan kebersamaan dalam aktifitas silat tercermin pada gotong royong anggota terutama pada saat berlang sung acara-acara pertandingan baik skala lokal, nasional maupun interna sional.

5) Kekuatan gotong royong dalam memelihara keberadaan silat, merupa kan potensi positif dalam meningkatkan pengetahuan masyarakat dalam pemeli haraan budaya melalui olahraga silat, sehingga di harapkan terjadi keseimba ngan antara pengetahuan secara turun temurun dan pengetahuan modern demi menjaga keberlangsungan tradisi silat Indonesia.

6) Dampak dari pendidikan beladiri silat dapat meningkatkan fisik dan mental peserta didik yang berimplikasi pada produktivitas.

7) Kekuatan dalam kebersamaan dalam berlatih silat tercermin dalam perilaku yang saling menguatkan dalam memak nai proses kehidupan berbangsa dengan mempertahankan identitas budaya melalui seni beladiri dan pemeliharaan kesehatan.

8) Kekuatan dalam saling membantu sebagai upaya memelihara identitas budaya merupakan potensi positif untuk meningkatkan pengetahuan masyarakat sebagai jatidiri bangsa yang berkualitas secara fisik dan mental.

9) Simbol seni beladiri silat merupakan sebuah jalan dalam meningkatkan pengetahuan masyarakat mengenai identitas budayanya. Memaknai identitas budaya tidak hanya sekedar pengetahuan tetapi silat dan praktek yang bermanfaat bagi pendidikan dan pemeliharaan kesehatan setiap generasi.

\section{Daftar Pustaka}

Alexander, Howard., Quintin Chambers., and Donn F. Draeger. (1972). Pentjak Sllat The Fighting Art of Indonesian Fighting Art. Tokyo : Kodansha

Barnard A. (2004). History and Theory in Anthropology. U : The Press Syndicate of The University of Cambridge.

Barth F. (1969). Ethnic Groups and Boundaries. London : George Allen \& Unwin.

Berger, P.L., Thomas Luckman. (1995). Tafsir Sosial Atas Kenyataan: Risalah Tentang Kenyataan Sosiologi Pengetahuan. Jakarta: LP3ES.

Bouchard, Claude. (1975). Problem of Sport Medicine and of Sport Training and

Coaching.Olympic Solidarity of the International Olympic Committee (IOC).

Creswell, J. W. (2014). Research Design. Pendekatan Kualitatif, Kuantitatif dan Mixed Method. Yogyakarta: Pustaka Pelajar. 
de Castella, T. (2006). Work Experience: Uanu seshmi, director, from boyhood to manhood. Regeneration \& Renewal, , 24. Retrieved from "https://search.proquest.com/docview/230688888?accountid=38628" [17/01/16]

Draeger, Donn F. (1992). Weapons and fighting arts of Indonesia. Rutland, Vt. : Charles E. Tuttle Co.

Geertz, Clifford. (1973). The Interpretation of Culture. New York: Basic Book Inc.

Geertz, Clifford. (1983). Local Knowledge. USA: Basic Books, Inc.

Gilang, Moh. (2007). Penjasorkes SMA kls XI. Jakarta : Ganeca Exact.

Kementerian Kesehatan RI. (2006). Pedoman kesehatan olahraga puskesmas. Jakarta : Depkes RI

Alexander, Howard., Quintin Chambers., and Donn F. Draeger. (1972). Pentjak Sllat The Fighting Art of Indonesian Fighting Art. Tokyo : Kodansha

Barnard A. (2004). History and Theory in Anthropology. U : The Press Syndicate of The University of Cambridge.

Barth F. (1969). Ethnic Groups and Boundaries. London : George Allen \& Unwin.

Berger, P.L., Thomas Luckman. (1995). Tafsir Sosial Atas Kenyataan: Risalah Tentang Kenyataan Sosiologi Pengetahuan. Jakarta: LP3ES.

Bouchard, Claude. (1975). Problem of Sport Medicine and of Sport Training and

Coaching.Olympic Solidarity of the International Olympic Committee (IOC).

Creswell, J. W. (2014). Research Design. Pendekatan Kualitatif, Kuantitatif dan Mixed Method. Yogyakarta: Pustaka Pelajar.

de Castella, T. (2006). Work Experience: Uanu seshmi, director, from boyhood to manhood. Regeneration \& Renewal, , 24. Retrieved from "https://search.proquest.com/docview/230688888?accountid=38628" [17/01/16]

Draeger , Donn F. (1992). Weapons and fighting arts of Indonesia. Rutland, Vt. : Charles E. Tuttle Co.

Geertz, Clifford. (1973). The Interpretation of Culture. New York: Basic Book Inc.

Geertz, Clifford. (1983). Local Knowledge. USA: Basic Books, Inc.

Gilang, Moh. (2007). Penjasorkes SMA kls XI. Jakarta : Ganeca Exact.

Kementerian Kesehatan RI. (2006). Pedoman kesehatan olahraga puskesmas. Jakarta : Depkes RI.

Martial arts and the body politic in indonesia (2015). Beaverton: Ringgold Inc. Retrieved from https://search.proquest.com/docview/1688712754?accountid=38628 [05/07/2017]

Kementerian Kesehatan RI. Undang-undang Kesehatan No. 36 Tahun 2009

Kinasih, Sri. E. (2009). Buku Ajar Antropologi Hukum. Surabaya: PT. Revka Petra Media.

Kumaidah, Endang. (2012). Penguatan Eksistensi Bangsa Melalui Seni Bela Diri Tradisional Pencak Silat. Jurnal Kajian IImiah Humaniora. Vol 16, No 9: Desember 2012

Lubis, Johansyah., (2004). Pencak Silat Panduan Praktis, Rajawali Sport: Jakarta.

Lubis, Zulkifli. (2011). Problema Sosial, Pandangan Hidup dan Konsep Kebudayaan. Antropologi Indonesia, p. 240.

Maalouf, Amin. (2000). In the Name of Identity. USA : Penguin Group

Mahendra, Aditya. (2013). Konstruksi Identitas Sosial Perguruan Pencak Silat Pencak Organisasi Ranting Kecamatan Sidoarjo, Kabupaten Sidoarjo. Journal Universitas Airlangga Volume 2 Nomor : 2, Juli 2013.

Maryono, O'ong. (2000). Pencak Silat: Merentang Waktu. Yogyakarta: Galang.

Belanawane, Muhammad. (2008). Identitas dan pengkonstruksiannya. Fisip UI. Retrived "http://lib.ui.ac.id/file?file=digital/123432-SK-007\%202008\%20Bel\%20iIdentitas\%20dan-Pendahuluan\%20Literatur\%20dan\%20Metodologi.pdf" $[22 / 01 / 17]$

Ortner, Sherry. B., (1984). Theories in Anthropology since the Sixties. Comparative Study of Society and History, Januari, Volume 26, pp. 126-166.

Paul B, Horton \& Hunt, Chester L. (1993).Sosiologi Edisi Keenam (Alih Bahasa:Aminuddin Ram \& Tita Sobari). Jakarta, Penerbit Erlangga.

Quintin Chambers, D. F. D., (1978). Javanese Silat : The Fighting Art of Perisai Diri. Tokyo: Kodansha International. 
Suwaryo. (2008). Peranan organisasi Perguruan Seni Beladiri Pencak Silat Dalam Meminimalisir Kejahatan (Studi Suatu Studi Upaya Non-Penal Pada Organisasi Perguruan Seni Beladiri Pencak Silat Di Kabupaten Banjarnegara, Provinsi Jawa Tengah). Semarang: Universitas Dipenogoro.

Spradley, James. P., (2007). Metode Etnografi. Kedua ed. Yogyakarya: Tiara Wacana.

Spyanawati, Ni Luh Putu. (2014). Hasil Belajar Jurus Tunggal Cabang Olahraga Pencak Silat. Jurnal IImu Keolahragaan Vol. 13 (1) Januari - Juni 2014: 13-22

Subroto, Joko., Moh. Rohadi. (1996). Kaidah-Kaidah Pencak Silat Seni yang Tergabung dalam IPSI. Solo: CV Aneka.

Paetzold, Uwe. U., Paul H. Mason. (2016). The fighting art of pencak silat and its music: From southeast asian village to global movement. Beaverton: Ringgold Inc. Retrieved from https://search.proquest.com/docview/1771512187?accountid=38628 [05/11/2016]

van Klinken, G. \& Berenschot, W. (2014). In search in Middle Indonesia :kelas menengah di kota-kota menengah. Jakarta: Yayasan Pustaka Obor Jakarta.

Wilson (2015) Martial arts and the body politic in indonesia. Beaverton: Ringgold Inc. Retrieved from https://search.proquest.com/docview/1688712754?accountid $=38628[05 / 11 / 2016]$ 